Makarova et al. (2021). International student exchange management as factor of educational services development, International Journal of Cognitive Research in Science, Engineering and Education (IJCRSEE), 9(1), 75-90.

Original scientific paper

UDK:

378:005.94

Received: January, 17.2021.

$37.014 .242-057.875$

Revised: February, 28.2021.

doi: 10.23947/2334-8496-2021-9-1-75-90

Accepted: March, 04.2021.

Check for updates

\title{
International Student Exchange Management as Factor of Educational Services Development
}

\author{
Elena A. Makarova ${ }^{1 *}$, Elena L. Makarova², Irina A. Egorova ${ }^{3}$
}

\begin{abstract}
'Department of Translation, Faculty of Humanities, Don State Technical University, Rostov-on-Don, Russian Federation, e-mail: makarova.h@gmail.com

${ }^{2}$ Department of Management and Innovative Technologies, Institute of Management in Economic, Environmental and Social Systems, Southern Federal University, Rostov-on-Don, Russian Federation, e-mail: elmakarova@sfedu.ru ${ }^{3}$ Department of Management, Taganrog Institute of Management and Economics, Taganrog, Russian Federation, e-mail: i.egorova@tmei.ru
\end{abstract}

\begin{abstract}
Since the beginning of XXI century higher education internationalization trend has been intensifying around the world. The goal of the research is to study managing international education characteristics to promote educational services export. Levels of interconnection and interdependence between economic agents around the world are increasing; transnational forms of economic activity, information and communication technologies are developing. The market for higher education is developing intensively as educational services of the highest international level demand is increasing. The research goal is to analyze the main economic tendencies in modern students' exchange programmes. The problems discussed are the need to increase educational services export by promoting it using various student exchange models, study of managing international education characteristics to promote educational services export and its development. For this purpose the methodology consisting of modeling educational policy processes and analyzing the results is used. The results of the study show that higher education takes on international socio-economic features, which are to be seen as an attractive investment target. Modern higher education is developing in the conditions of open access and mutual influence of conditions in different countries, depending on the basis of economic, political and cultural relations. The growing interest in education abroad leads to existing paradigm of educational services management review thus updating this study's topic. In the conclusion we highlight that integrative processes in internationalization of education management can significantly enrich practical application in this sphere. Recommendations in this study can be used to increase educational services export and import.
\end{abstract}

Keywords: student exchange, education management, education export, international education, academic mobility.

\section{Introduction}

Many scholars note that "information, knowledge and innovations, as well as ways of their practical application, are increasingly considered as a source of profit in a post-industrial society" (Ussenova et al., 2020). In this situation, education has taken a leading place in the world economic development, increasing labour productivity, human capital quality, and the long-term results of the social production efficiency growth. According to British scholars Bridges and Bridges (2017); Menzies and Baron (2014), "transnational education refers to all types of higher education programs, complexes of educational courses or educational services, dual enrolment opportunities, summer bridge programs and team projects". Such programmes can be provided by a country's educational system or may be independent of any systems at all. International students' exchange may be studied theoretically and applied practically. According to different researches' meta-analysis, the main problems of students' exchange are the institutionalization of international education and management of students' needs, psychological and social support shapes and structure, and the transition from the national to international. Thus, "research focuses on the methods of internationalization at the individual, institutional, and national levels" (Bedenlier et al. 2018, p.108).

So far, international education has significantly changed its direction. The term "education export" has appeared. The programs of double and multiple diplomas, the International affiliations of the world's leading educational institutions, franchised universities and joint programmes of international education Corresponding author: makarova.h@gmail.com

(c) (i) 2021 by the authors. This article is an open access article distributed under the terms and conditions of the Creative Commons Attribution (CC BY) license (https://creativecommons.org/licenses/by/4.0/). 
Makarova et al. (2021). International student exchange management as factor of educational services development, International Journal of Cognitive Research in Science, Engineering and Education (IJCRSEE), 9(1), 75-90.

have been developed. There is an urgent need in standard procedures, educational quality criteria, regulatory policies and tendencies monitoring development. "The international protocol for worldwide collection of transnational education data is developing, similar to what United Nations Educational Scientific and Cultural Organization (UNESCO) and Organization for Economic Co-Operation and Development (OECD) do for international student mobility" (Knight, 2016, p.34).

Researchers argue that political factors are overestimated, but the need for systematic longterm planning is underestimated. Anyway, the internationalization of education and academic mobility programs are neither uniform nor linear. They are aimed at long-term processes, the results of which are uncertain, since they are difficult to predict in the context of rapid social, political and economical change (Dakowska, 2017, p.588). Specific tasks include joint educational programs and double-degree programs facilitating the new programs development, knowledge and experience sharing; individual teachers' mobility programs, visiting professors' lectures delivering etc. International students' and teachers' mobility consists of "training, data collection for research, internships, job shadowing, a staff training week attending, joint projects implementation" (Makarova, Makarova and Hjaltadottir, 2019). Thus, experience shows that international exchange programs and students' support are effective when they are established on the foundation of the development of the national education system priority areas. For example, the International Baccalaureate program existing in a number of world universities is focused on intra-personal, inter-personal qualities and pro-social development. It pays attention to the holistic development of personal traits, including pro-social behaviour shaping (Bailey and Cooker, 2018 p.228).

Staff mobility plays a significant role in international education development. The involvement of foreign professors and researchers into university activities is "one of the competition areas in the international market of educational goods and services" (Ismailova et al., 2020). The world's leading universities usually have an international team of scientists and professors; foreign teaching staff percentage in the educational process is one of the most impressive indicators in the world's leading universities rankings. The world leader in international education development is the United States of America. According to statistics, foreign professors make up $33 \%$ of the total faculty at the US universities, while in Russian universities the share of foreign instructors ranges from 0 to $5 \%$, most of them in leading institutes or federal universities in Moscow. Foreign professors Invitation targets achieving several academic and non-academic goals, the major one being the university's competitive qualities development and the ranking in the world system. Mentioning other goals, we call the range of educational programs expansion, which means integrated and joint training programs inclusion, English language education programs implementation, compliance with international educational standards and demands, new research areas development demanded by the global scientific community, development of the university's positive image, and improvement of its recognition in the world.

An important tendency in the world education development is the introduction of digital and network technologies into education and transition to online learning, having two sides. First of all, digital technologies, gamification, edutainment are substituting traditional classroom learning. "New information technologies are becoming an important aspect of the international educational context as much as the content of education and the people who participate in it" (Mcvicar, 2015).

Another educational trend is educational organizations integration. This includes various participants in educational goods and services market, involving potential employers, national and international services providers, even those companies that have never dealt with educational goods and services before. Another effective tool in the world market of educational goods and services competition has been the growth of mergers of academic institutions or integration of individual institutions as faculties of universities or academies. The universities in Finland, for example, are heading most consistently in this direction; as a result of the merger, new educational institutions are being formed to become leaders in national education. Similar processes take place in Denmark: 8 universities and 3 research centres were established out of 25 universities and research centres. The expansion of universities in Europe and the USA during the last 20-30 years is a global tendency. Among the objectives of this tendency, experts usually highlight the universities intention to improve not only their performance in the national market of educational goods and services, but also their international rankings.

As noted by Knight J. (2018), "there are three different principles underlying the formation of educational hubs as a new form of international educational centres - the student hub, the talent hub, and the knowledge and innovation hub". Such integrated units can be built upon three different foundations. They can be focused on students engaged in the recruitment of foreign citizens eager to get education in RF. In addition to student recruitment, such centres are developing new promising joint or franchising programs, double and multiple diplomas programs, targeting not only foreign, but also local students.

Another type of educational integrators is the centre of talent; their main task is human resources 
development. The main goals of such integrators are expressed in attracting talented youth and skilled workers from abroad. Educational integrators of the third type are Knowledge and Innovation Hubs; their main activity is scientific research for the production and dissemination of new knowledge and introduction of innovations. The goals of such integrators are the creation of favourable conditions for research activities, foreign investments attraction, competitiveness of applied scientific research development and increase (Buckner, 2017 p. 296).

According to Organization of Economic Cooperation and Development, "the number of students getting education outside their own country) increased threefold from 1990 (1.3 million people) to 2011 (4.3 million people)". According to the UNESCO forecast," the number of students learning outside their native ciuntry will reach 7.2 million by 2025" (Amirov, 2018). This perspective is associated with the state education regulation intensification in many countries. "Annually different international higher education scholarship programs attract a significant amount of funds from national governments, supranational organizations, large charities, higher education institutions and many other smaller organizations. Internationally targeted scholarships fund students in higher education institutions around the world" (Mawer, 2017). The US government identifies promising in the area of education target countries, recruits educational institutions that are interested in expanding their international involvement and foreign students' enrolment, and promotes these programs to students, teachers, and educators in the target market also providing assistance in receiving certain types of scholarship and grants. Education ranks fourth in terms of exports, second only to exports of dairy products, tourism and meat. In addition, international education makes a significant contribution to the labour market and supports world's economy.

In Russia Global Education state program was recognized and successfully implemented in many state educational institutions in 2013. Russian education export system has a great developmental potential, as many foreign experts have noted; budgetary revenue from educational services export will grow from 78 billion rubles in 2017 to 198 billion rubles in 2025. Financing is through contributions of the RF budget and private donations from sponsors' to a special educational fund. The program participant's fees for tuition; accommodation; transportation costs and educational resources are paid through the fund in advance, while medical insurance and personal expenses are reimbursed. The largest number of universities approved by this Program is in the countries whose universities are leaders in higher education (the US, Great Britain, Germany, and Canada). Improvement of Russian education competitiveness in the international market of educational goods and services is associated with the internationalization strategies for education system levels development and improvement.

\section{Materials and Methods}

\section{International Education Management: Models and Educational Policy Processes}

Management of higher education, including international, has its own peculiarities, associated with the special status of higher education institutions. On the one hand, universities are educational, scientific and cultural centers that meet the requirements of society and the state in preparing professionals needed by the economy and in increasing new knowledge and innovations. This is the social significance of universities. On the other hand, universities are included in the market of educational goods and services as entities producing and selling services. This is the economic importance of universities as full-fledged subjects of market economy (Pashakhina, 2020 p.110).

According to Etzkowitz H. (2016), universities acquire entrepreneurial traits, transforming knowledge into economic activity, playing a creative role in the economic and social development of education both at the state level of one country and in the international education market. There is a clear idea that despite the participation and various external factors influence, the three main actors in the educational policy are the state, an educational organization and business (Cai and Etzkowitz, 2020).

Speaking about the adaptability of each model to a rapidly developing market, we should note that the one with the greatest variety of educational activity agents, sources of financing, a high level of educational organizations autonomy and academic mobility will be most adaptable. With regard to the management of international education in Russia, it is necessary to distinguish three levels of the agents: federal, regional and university (Bondarenko et al., 2018, p.6).

At the level of federal government and departments, state policy target guidelines in the field of international education and educational services export are set; priority federal projects in the education field and the main directions implementation are developed. The objectives of the state educational policy are to expand the export of educational goods and services as a form of non-resource export, the inflow of labour capital, attracting talented foreign students, Russian education brand promotion abroad, and 
Makarova et al. (2021). International student exchange management as factor of educational services development, International Journal of Cognitive Research in Science, Engineering and Education (IJCRSEE), 9(1), 75-90.

Russian language and culture popularization among foreign citizens.

The following frameworks are being developed at the federal level: framework governing foreign students' entry into the country; a system of quotas for foreign students; bilateral agreements between states.

International education management at this level has a number of features:

- territorial support programs for academic mobility are developed and implemented,

- information centers are created to support, adapt and interact foreign students with the local community,

- procedures are developed to solve the problem of foreign citizens studying in the region employment.

These activities entrepreneurial nature allows for a new way of presenting and flesh out the main functions of the educational organization of higher education in international activity. The university's traditional business functions are teaching and training; researching, marketing, financial and economic activities.

According to researchers (Gaus and Raith, 2016), education, research and entrepreneurial functions are included in the university's business process system. The international activity of educational organizations allows for the use of the above mentioned business processes. Management of these university business processes is carried out in the following areas: financing sources that provide funding; distribution channels through which it is transmitted; customer segments as the main target purchasers of goods; sources of revenue generation; costs implementation directions (Silakova, 2017).

Entrepreneurial business process is expressed in the diversification of educational services, educational programs of various durations, target audience, level of education, and technologies applied in teaching and training. An important part of the entrepreneurial process is the expansion of consulting services range for the state, business and citizens and these services launch into international market.

Summing up the results of theoretical analysis, a number of basic principles are formulated. Modern international education develops very intensively. The main trends are related to integrative processes in higher education, increasing academic mobility level, strengthening state regulation role, digital and network technologies, as well as individualization of educational trajectories for talented students.

Analysis of the Global Market for International Education. The global market of educational goods and services is developing rapidly involving all countries of the world. Researchers say that international education market development has both economic and social significance. Education as a type of service is a special line of business, and today the leading players in this market receive substantial income from training foreign students. In educational economy, knowledge is the main factor in goods and services production. Economy based on knowledge has succeeded in creating prosperity and wealth with participation of gifted and talented people, high intelligence, professional skills, and a wide range of diverse demands from society and the Government.

According to OECD estimates, around 140 million students in the world are studying in 36 thousand higher education institutions. Most of them get education in their own country. However, the number of students studying abroad is growing rapidly. According to UNESCO, the number of international students in the world is growing steadily; in 2017 it amounted to more than 5.341 million people. As shown in Figure 1, in 2000 this indicator was at the level of 2.1 million, in 2003 it was 2.65 million, in 2007 it overcame the mark of 3 million, in 2013 it exceeded 4 million, and in 2016 it reached 5 million people.

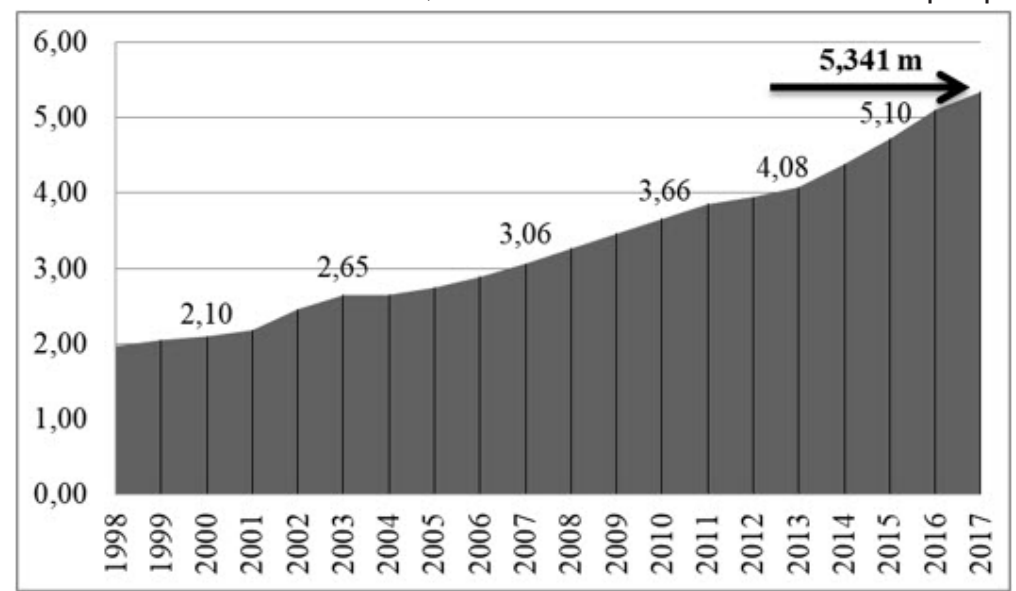

Figure 1. The number of international students in 1998-2017, million people 
The main segment of the international educational services market is higher education programs. The share of countries participating in the educational market of goods and services is heterogeneous. Today, this market prevailed mainly in three countries in different parts of the world: the USA, Great Britain and Australia, all of them are English-speaking.

Figure 2 shows the latest OECD (2019) data on the market for international educational services, the share of foreign students studying in each country of destination, in terms of all mobile students in the OECD and partner countries. As shown at Figure 2, the leading positions are occupied by the United States, teaching $22 \%$ of all international students of the world, the UK is second with a share of $10 \%$, Australia is third $(9 \%)$, having recently significantly strengthened its position in the educational market. Fourth, fifth and sixth places are divided among three countries of Europe - the Russian Federation, France and Germany (6\% each).

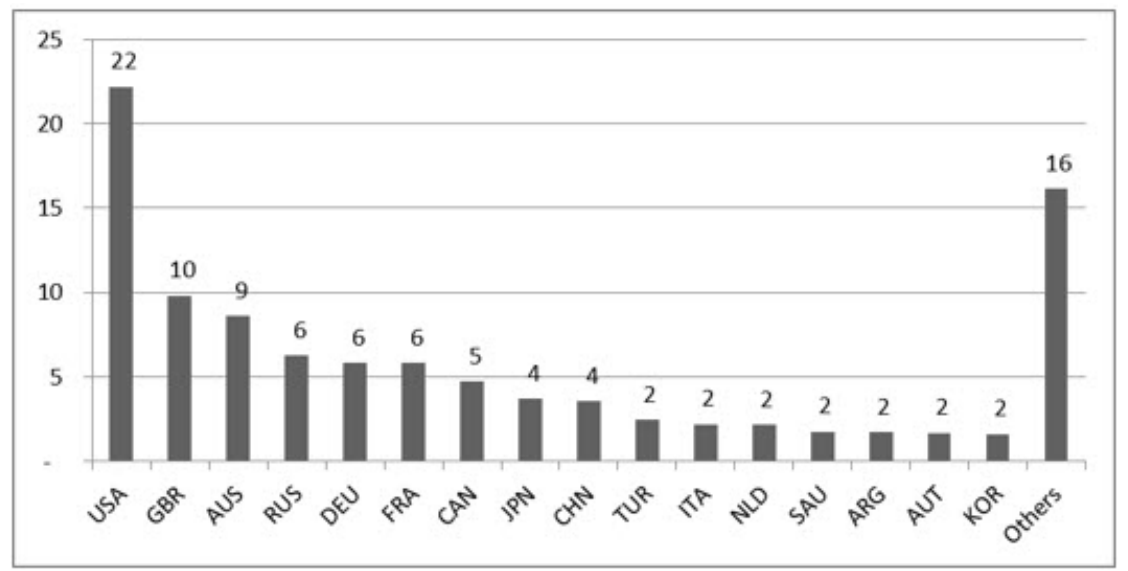

Figure 2. International students enrolled in each destination country as a share of all mobile students in OECD and partner countries (2017), \%

Thus, students mostly study in Europe, where they are distributed across several countries (France, Germany, the Russian Federation, Austria, Italy, the Netherlands, Turkey and others). Although North America takes fewer students in absolute terms, the United States holds firm leadership positions not only on the continent, but also in the world. A large number of foreign students in English-speaking countries indicate a high level of interest in English-language education. Table 1 shows the dynamics and changes in the percentage of foreign students studying in a particular country.

Table 1

Percentage of foreign students in the given country $(2010,2013,2017)$

\begin{tabular}{cccc}
\hline \multirow{2}{*}{ Country } & \multicolumn{3}{c}{ Percentage of foreign students } \\
\cline { 2 - 4 } & $\mathbf{2 0 1 0}$ & $\mathbf{2 0 1 3}$ & $\mathbf{2 0 1 7}$ \\
\hline Australia & 22,08 & 17,97 & 21,48 \\
United Kingdom & 16,04 & 17,46 & 17,92 \\
Canada & no data & 9,72 & 12,92 \\
France & no data & 9,78 & 10,20 \\
Germany & 7,99 & 7,07 & 8,37 \\
United States & 3,54 & 3,87 & 5,18 \\
Japan & no data & 3,43 & 4,27 \\
Russian Federation & 2,02 & 1,84 & 4,08 \\
\hline Source: OECD/UIS/Eurostat (2019). & & &
\end{tabular}

As can be seen from the data, Australia holds the leading position in this issue, where the share of foreigners is the highest - from $17 \%$ to $22 \%$. A large percentage of foreign students is traditionally seen in the UK (16-17\%, and the percentage is growing). Positive dynamics is in Canada (9-12\%), the USA (3-5\%) and the Russian Federation (1-4\%). However, among the leading countries in the international market of educational goods and services demonstrated in Table 1, Russia occupies the lowest position; it is in the eighth line. Comparing other data, we can say that postgraduate education of foreign students is one of the most important areas in the global educational services market. High percentages for master's and 
Makarova et al. (2021). International student exchange management as factor of educational services development, International Journal of Cognitive Research in Science, Engineering and Education (IJCRSEE), 9(1), 75-90.

doctoral programs are noted in all countries - leaders of the international education market. According to doctoral programs, the first place belongs to the UK (42.1\%), according to master's programs - to Australia $(47.7 \%)$. An interesting trend is found in Australia - a rather high percentage of short-term students $(20.2 \%)$. In Canada, this share is $12.7 \%$, and for the rest of the market participants this segment of educational services is poorly represented or not represented at all, as in Germany, for example. Meanwhile, shortterm educational programs are becoming increasingly relevant in the context of individual educational trajectories and the concept of life-long education. Development of short-term programs (for example, for improving language competencies in a native language environment) can become a significant advantage for the country in the international educational services market.

All countries of the world that are the major players in the educational market and in the export of educational goods and services can be divided into two main groups - hard and soft sellers. The hard sellers in the market of educational goods and services are Denmark and the UK in Europe, Argentina and Brazil in South America, Canada and the USA in North America, India, Australia, and New Zealand in other parts of the world. In these countries the universities occupy the highest positions in the world rating that is why the tuition fee is usually threefold compared to other universities of the same rank in other countries. For soft sellers, the tuition fee for foreign students is compensated by payments from the budget sources. For example, in Germany, France, Finland, Sweden, foreign students do not pay for their study in state universities, but have to pay if they enter some private educational institution. Thus for such a country that provides educational goods and services, the profit from educating foreign students is not in a tuition fee, but in money paid for accommodation, food, travelling, entertainment, books, stationary etc. In addition, such countries get profit when they attract educated emigrants to their labour markets who will stay in the country after graduation and start working in different areas of economics.

Tuition fee is also a sophisticated financial mechanism that can regulate the domestic market of educational goods and services. For example, in Great Britain EU countries students' expenses are completely different from those of other countries' students (depending on the status of the university), but these expenses are lower for British citizens anyway. In this way, the university gets enough money for its existence and prosperity without raising prices for national students training.

With such a sophisticated market strategy, the university can meet the requirements of the national industry development and innovative technologies introduced; the need in skilled staff; demographic changes; standardized legal space, national government attitude to education in general, education development and advance in compliance with the progress, etc. Without taking all these factors into account, expanding the borders of the market and increasing profits are not possible; exports in general are not conceivable.

There are many TNCs: DAAD (Germany), British Council (Great Britain), CIMO (Finland), IDP Education Australia (Australia), EduFrance (France) and others. Some of them are engaged exclusively in education, and some are in related areas - culture and art. The daily practice of TNCs includes hundreds of projects: they support development and distribution of national language programs, arrange student and staff mobility, provide support in information dissemination and advisory services, etc. The TNC format has proved to be extremely productive both for students and staff.

A significant part in students' mobility setup is played by international unions and organizations with academic focus. NAFSA (Association of International Educators) is the world's largest non-profit association dedicated to international education and academic exchange. NAFSA's 10,000 members are located at more than 3,500 institutions worldwide, in over 150 countries. European Association for International Education (EAIE) is the European centre where experts work creating networks and resources and providing higher education globalization. EAIE is a non-profit, non-governmental organization helping people worldwide to get education in a foreign country through a combination of academic training, scientific conferences and forums, knowledge dissemination and sharing. EAIE assists academic and non-academic professionals in their challenge to get through; by providing opportunities of international exchange. EAIE partners promote membership interests and advance international higher education in Europe and in the rest of the world. These organizations show that the international market for educational goods and services can be structured from different points of view, not from the point of financial profit, but of academic and scientific benefit for the whole mankind. This market includes enrolment of students, establishment of campuses and branches abroad, as well as distance learning.

Features of Educational Services Export Management in Russia. The first lines in the ranking of the best world universities are consistently occupied by the universities in the USA and the UK. Traditionally, the group of countries with a developed education system also includes Switzerland, Australia, Canada and China. According to QS World University Rankings 2020, Moscow State University remains the best Russian university in the QS ranking - $84^{\text {th }}$ place, rising six positions compared to last year. The second 
place among Russian universities was occupied by Novosibirsk State University (231 ${ }^{\text {st }}$ position), the third St. Petersburg State University (234 ${ }^{\text {th }}$ position). In total, 25 Russian universities entered the top 1000 , with 15 of them improving their positions constantly. Massachusetts Institute of Technology (MIT) has been recognized as the best in the world for the eighth consecutive time.

In 2017 the RF Government adopted an academic document "Export potential of the Russian educational system development" containing predictions of results and methods for achieving goals in the field of expanding the education export potential of the RF by 2025. The key goal of this academic project is to significantly increase Russian education's competitiveness in the international market of educational goods and services and thereby to enhance non-resource exports of Russia. For this programme implementation it is necessary to design and develop the university's versatile strategy in the education export, it is also necessary to mold certain services to support foreign students. By implementing this project the RF Government is planning to attract full-time students from foreign countries up to the number of 510 thousand people, and the extra-budgetary funds received from the Russian education export will go up to 303,147 million Russian rubles.

The Russian statistical collections (Federal State Statistic Service) prove that every year the number of foreign students in higher education programs is increasing. Comparing predictions with the real numbers, we can see that over the period of 5 years, the total number of foreign students has grown by 64,442 people, full-time students by 41,296 people. The number of foreign students enrolled in RF universities is steadily growing, and the number of foreign universities participating in the priority project is growing (Figure 3). At the moment there are 39 of them, but according to the project, by 2021, all the Russian universities should use the "Model for education export."

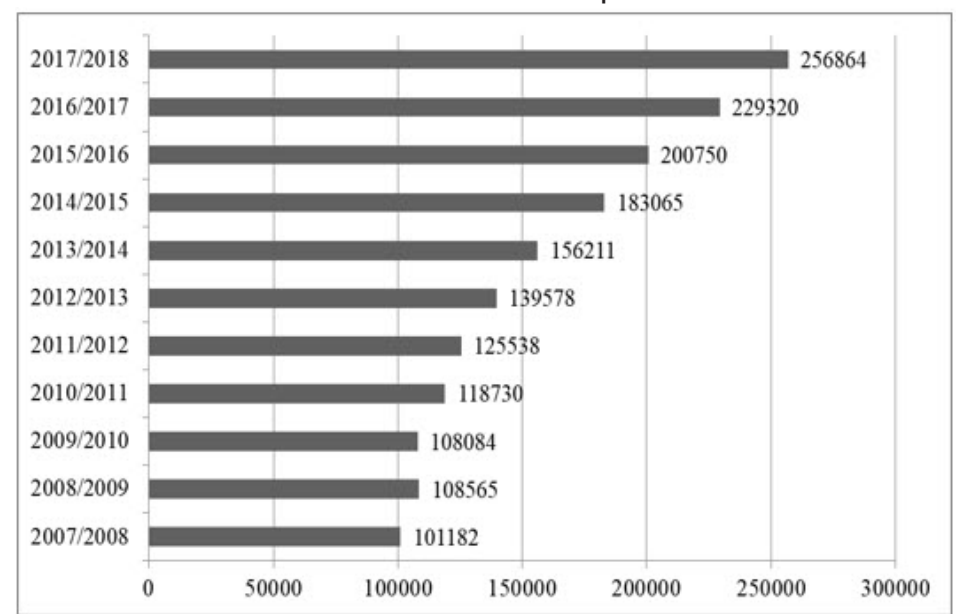

Figure 3. Foreign students enrolled in Russian universities (2007-2018), people

Source: Russia in numbers. 2007-2019. Rosstat

The percentage of foreign students enrolled in RF universities at all the levels is growing steadily. Fig. 4 shows the ratio of foreign students to the total number of students (percentage). As can be seen from the data presented, in 2017 this share was 7.1\% and over the past few years has grown several times.

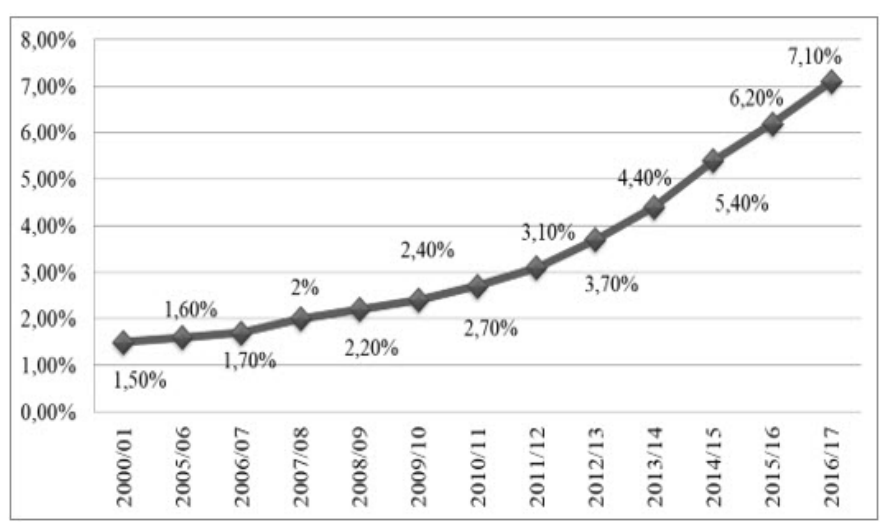

Figure 4. The ratio of foreign students to the total number of students in RF universities (2000 2017), \%

Source: Russia in numbers. 2000-2018. Rosstat 
According to statistics, about $80 \%$ of all foreign students study at the undergraduate level; this percentage has grown steadily over the course of several years (from $63.48 \%$ in the 2006-2007 academic year to $80 \%$ in the 2017-2018 academic year). The share of students in the Master's program ranges from $14.15 \%$ in $2014-2015$ to $23.36 \%$ in $2009-2010$, while there is a tendency for reduction. In 2017 2018 academic year, the share of students in the Master's program is about $15 \%$. As for post-graduate education, an even more significant decrease is observed in this sector of education - from almost $15 \%$ in 2006-2009 to $4.85 \%$ in the 2017-2918 academic years. It can be concluded that foreign students are more interested in obtaining a bachelor's degree in higher education institutions of the Russian Federation than in Master's or Doctorate programs.

The success of educational services export depends to a great extent on the number of students getting education on a commercial basis and on the cost of training. Fig. 5 presents the dynamics in the increase of foreign students enrolled in higher education institutions on a commercial basis in 2014-2018. As shown, this indicator decreases annually, with the largest drop in 2015. Further, the decline slowed down, but the number of the countries exporting students continues to decline.

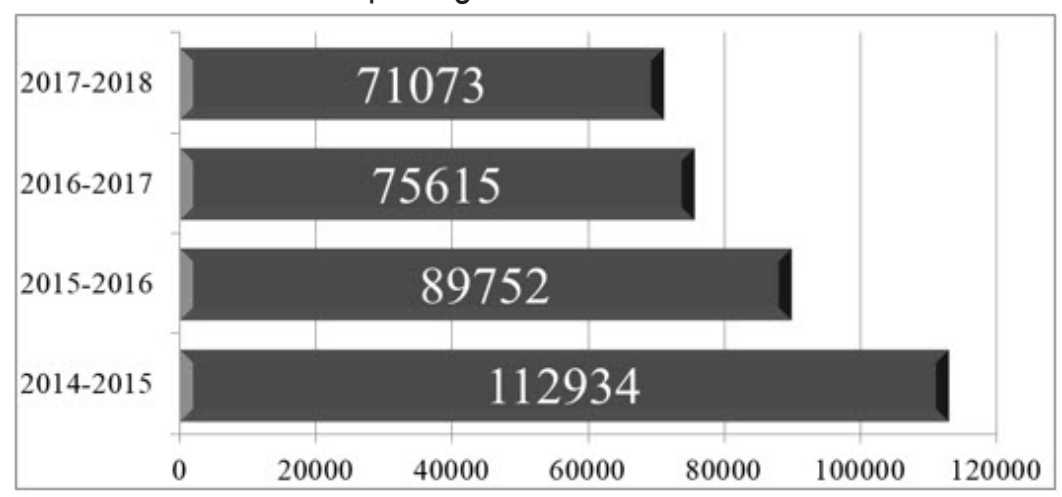

Figure 5. The number of foreign citizens studying in higher education organizations on a contract basis for 2014-2018, people

Source: Russia in numbers. 2014-2019. Rosstat

In 2018, according to the statistical digests, the number of foreign students was grouped into those who studied in state or community universities, and those who studied in private educational institutions. In 2015-2016 there was a slight decrease in the number of foreign students enrolled in private educational institutions. Income from the export of educational goods and services is presented in Figure 6 . The revenues of state and municipal universities from the export of educational goods and services are expectedly higher than those of private ones, but there is a noticeable upward tendency in both groups.

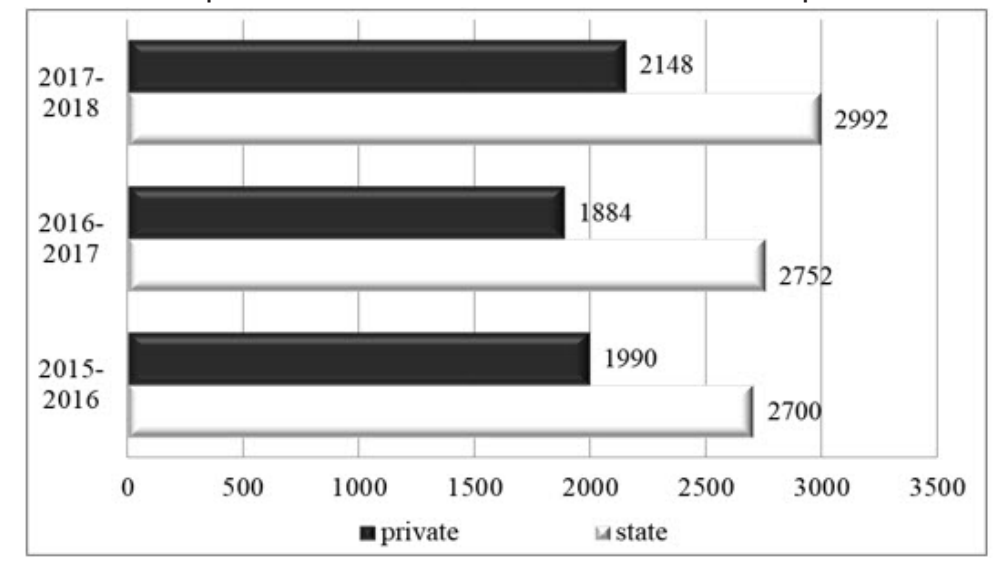

Figure 6. Total tuition fees for foreign and international students in public and private educational institutions of the Russian Federation, million rubles

Source: Russia in numbers. 2015-2019. Rosstat

All the foreign students enrolled in RF universities are unevenly distributed across the regions of the country. Russia is not a very successful player in the export market of educational goods and services, but strengthening its position from day to day. This is facilitated by the implementation of state priority projects and models for managing international education. 
Makarova et al. (2021). International student exchange management as factor of educational services development, International Journal of Cognitive Research in Science, Engineering and Education (IJCRSEE), 9(1), 75-90.

Models for Managing International Education and Promoting Educational Services Abroad. Currently, each country as a serious player in the market of educational goods and services is making special efforts to internationalize educational services. This is done both at the state level and with publicprivate partnership, as well as mutually beneficial triangular relations between the state, business and education. Hawawini G. (2016) describes five models of internationalization of education: Export Model, Import Model, Academic Joint Venture Model, Partnership, Alliance \& Consortia Model, Foreign Campus Model.

Export Model is implemented for educational services distribution abroad, attracting foreign and international students to study in full-time programs. Upon educational program successful completion, foreign students receive a degree, diploma or certificate. Such students pay for their studies either on their own, or with grants and scholarship support by non-governmental and non-profit organizations and endowment funds (Makarova, Makarova and Korsakova, 2019). There is an indirect option for foreign students, when they study without paying tuition fee, but at the expense of the host state. However, they pay for accommodation, meals and other household and cultural needs. The economic effect is the sum of all foreign students' expenses during their stay on the territory of a host state.

Import Model suggests foreign instructors' involvement. Knowledge and experience that foreign experts possess is imported, and an educational institution profit depends on the number of students enrolled in a visiting professor's course. Often the result of such a model implementation is certificates of additional education received. International education may exist as an inclusive education program. By participating in this program, a student studies at a leading university and receives a diploma, while participating in a course offered by a partner university, with the subsequent issuing of a certificate of additional education. Examples of such a model can be found in almost every Russian university, where foreign teachers work. Leading universities implement various programs for foreign teachers' recruitment (Fellow, Post-Doctoral Fellow, or Visiting Professor programmes).

Academic Joint Venture Model is implemented in joint educational programs with double and multiple diplomas granted. At the same time, students have the opportunity to study full-time at least one or two semesters in a foreign university that is a partner of their national university. Graduates receive not only a "double set" of knowledge and competencies, but also a double diploma. This model is called the model of joint educational programmes, while it comes to the joint participation of two or more educational organizations in the design and implementation of the curriculum.

An alternative to this model can be a double diploma programme. Such programmes are characterized by the standards of terms and documents about education - a student studies at a foreign university for a long time and gets two diplomas of higher education. At the same time, the areas of training and majors can both coincide or vary. A student is enrolled in both universities simultaneously or sequentially and can study according to a jointly developed integrated curriculum. The economic effect of joint educational programs is associated with various options for tuition fee, but the greatest efficiency is in all educational organizations participating in joint educational programs promotion.

Partnership, Alliance \& Consortia Model is considered as the basis for any interaction programs between educational and scientific organizations. Bilateral and multilateral agreements are signed, scientific and educational clusters are formed, including joint research projects, business incubators, and support for talented young scientists and entrepreneurs. In theoretical review, such a model is called a network university. This title contains an emphasis on educational activities, although network universities are also involved in science and entrepreneurship. Within the framework of network universities, educational programs are implemented, with pre-university training, summer schools, language courses, cultural exchange programs of particular importance.

Foreign Campus Model is a network of central university foreign branches with a developed network structure and general educational programs. Students get the opportunity to study at a university abroad remaining in their own country but participating in the work of this university branch or affiliation. According to the definition given by The Observatory on Borderless Higher Education experts, "a foreign branch of the university is its unit that meets the following criteria: managed directly by this university or jointly with a foreign organization, but on equal terms and acts on behalf of this university; graduates of the branch who study only in their country receive exactly the same diploma as graduates of the head university" (Bischof, 2014, p.16).

The sixth model which can be added to this description in modern conditions has received extremely widespread development - is Cross-border Online Education Model. Depending on the goals of the educational process, each educational institution can diversify its own online teaching and learning in its programmes. Undoubtedly opportunities given by online teaching, gamification, virtualization and digitalization in education allow overcoming time and space, decrease academic restrictions, provide 
greater accessibility to special needs students compared to off-line classes. New technologies widen horizons and provide for internationalization of education all over the world.

Globalization helps with the transition to a digital academic environment, with corresponding digital competencies development of all the participants in the educational process. Digitalization along-side with globalization can completely change educational environment, the way of learning; competencies to be developed, educational institutions and criteria for evaluating students' success and progress. "Promising areas of digitalization are the use of simulators, project and collaborative learning technologies, adaptive and intuitive educational environment, mobile training applications, remote and virtual laboratories, and publicly available research data accumulation" (Barabanova et al., 2019, p. 94). Transition to digital education advantage is the development of general cultural competencies. All the gamers on this field improve their skills in solving problems, making decisions, processing information, communication, teamwork, understanding, self-knowledge and self-development (Makarova and Makarova, 2018, p. 57). The e-learning in European Higher Education Institutions report (Gaebel et al., 2014) notes that students with disabilities are interested in international online education, foreign students who choose online education as a more affordable alternative to full-time study abroad, working students and trainees advanced training, unemployed retraining, graduate students and adults who consider learning as leisure training.

There are several reasons that determine online education growing popularity. A significant impetus to its explosive growth was created by the situation of the forced self-isolation and the development of distance learning technologies during the COVID-19 corona virus pandemic. However, even before the pandemic, the online market of educational goods and services annual growth was registered at the level of $1.5-2 \%$. This can be explained by the fact that online education makes it possible to get enrolled in a foreign university course, to listen to lectures and to go to classes, to receive foreign certificates, degrees and diplomas without leaving the comfort of your house.

According to Internet World Stats, the Russian-speaking audience of Internet users is growing rapidly. In 2020 its number was more than 116 million people, which is $2.5 \%$ of all Internet users, and has significant growth indicators. The leaders in this regard are English and Chinese languages. Based on this, one can talk about so the need to develop online courses in English and Chinese.

The priority state project "Modern Digital Educational Environment in the RF" sets goals to bring the number of online students up to 11 million people, and to develop at least 4,000 online educational courses and programs. For this project implementation, it is planned to attract 3,200 million Russian rubles from budgetary and extra-budgetary funds, the allocation of grants to form a system of requirements for the legal, organizational and technical support of online educational programmes, to assess their quality, and to improve teachers' qualification in online teaching.

Each of international and export of educational services models described above poses the issue of promoting educational services abroad and attracting foreign students. To attract foreign students and to diversify the number of participating countries, universities use various forms of recruiting: educational exhibitions and fairs; competitions, creative contests, career counselling events; online recruiting tools, posting information on social networks, the mass media; expanding opportunities and conditions for foreign students employment; national state and commercial educational portals together with international educational agencies and global students exchange programmes; designs of official university sites both in national and English languages; brochures and leaflets for foreign students distributed in embassies, representative offices and other state and public structures abroad; participation in international ratings, national scholarship programmes, spreading information through associations of foreign graduates; active marketing of educational programmes; and participation in network universities. All these increase the international recognition of educational institutions, contribute to educational services abroad promotion, and increase education exports.

\section{Results}

Taganrog Institute of Management and Economics in Taganrog, Russia has majors in economic sciences and law. Its graduates are highly qualified specialists of a new generation who can easily adapt to the system of market relations, solve legal and financial issues in a modern way, and apply new technologies. International activity is one of the priority areas because it makes possible an exchange of scientific and cultural information, study of country's economic and political structure, and educational space possibilities expansion. With a bachelor's degree graduates can continue studies abroad.

TMEI entered into agreements with foreign educational organizations, including Bergstadt 
Makarova et al. (2021). International student exchange management as factor of educational services development, International Journal of Cognitive Research in Science, Engineering and Education (IJCRSEE), 9(1), 75-90.

Gymnasium (Germany), Logos Centar and Center for Business Studies colleges (Bosnia and Herzegovina), Janos Kodolanyi University of Applied Sciences (Hungary). The exchange of students and teachers through the use of joint international projects is very productive for solving assigned tasks in cooperation.

Each of the selected alternatives corresponds to one of the models of higher education internationalization and educational services export described above. Summer courses are the implementation of the export model, visiting professors' lecturing is associated with the import model, online courses implement the e-learning model, and double degree programs are the academic joint venture model (Fig. 7).

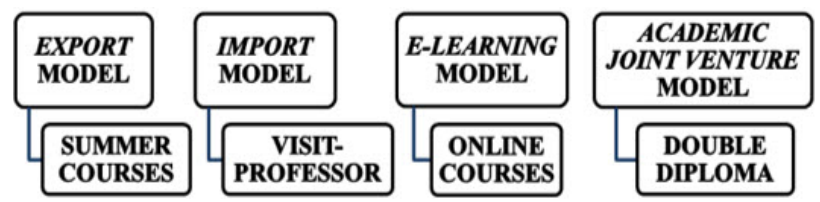

Figure 7. The relevance of the proposed measures and models of internationalization of education

Competencies necessary to comply with the requirements of new tendencies are project activity participation, team-work abilities, systemic thinking, time and process management, decision-making skills, intercultural and interlingua communication, English language oral skills, multifunctional and allpurpose universality in uncertain situations.

All the criteria of the international education successful model are ranked by their importance; the most important is compliance with the national educational policy, less important one is appeal for students and the least important is the cost of one student's training. As the basis for the analysis the criteria of cost, students' number, competences, training time, diploma/ certificate, students' interest, flexibility were taken. These criteria and values are presented in the Table 2.

Table 2

Description of criteria and their significance

\begin{tabular}{|c|c|c|c|}
\hline Criteria & Goal name & $\begin{array}{l}\text { Goal weight } \\
\text { factor }\end{array}$ & $\begin{array}{l}\text { Normalized weight } \\
\text { factor }\end{array}$ \\
\hline cost & To minimize cost & 4 & 0,2 \\
\hline $\begin{array}{l}\text { students' } \\
\text { number }\end{array}$ & To maximize the number of students & 2 & 0,1 \\
\hline $\begin{array}{l}\text { compe- } \\
\text { tences }\end{array}$ & $\begin{array}{l}\text { To raise the compliance with the national educational project } \\
\text { (competences number) }\end{array}$ & 5 & 0,25 \\
\hline time & $\begin{array}{l}\text { To minimize the time of training /to maximize the training } \\
\text { intensity }\end{array}$ & 4 & 0,2 \\
\hline $\begin{array}{l}\text { diplomal } \\
\text { certificate }\end{array}$ & To increase the importance of diploma, degree or certificate & 2 & 0,1 \\
\hline interest & To maximize the appeal for students & 1 & 0,05 \\
\hline flexibility & To maximize the flexibility & 2 & 0,1 \\
\hline & TOTAL SUM & 20 & 1 \\
\hline
\end{tabular}

As it can be seen from the data presented in Table 2, the most important criteria are competencies, costs, and time of training. The least important are interest, students' number and the course flexibility. The description of alternatives is presented in Table 3.

Table 3

The description of alternatives according to the selected criteria

\begin{tabular}{ccccc}
\hline Criteria & Summer courses & Visit-professor & Double diploma & Online courses \\
\hline training cost per 1 student & 1600 rub & $6000 \mathrm{rub}$ & $100000 \mathrm{rub}$ & 1000 rub \\
students' number & 15 & 50 & 5 & 50 \\
competences & 3 competences & 2 competences & 4 competences & 3 competences \\
time & $40 \mathrm{~h} / 2$ weeks & $72 \mathrm{~h} / 1$ month & $6 / 12$ month & $72-600 \mathrm{~h} / 1-6 \mathrm{month}$ \\
diploma/degrees/ certificate & certificate & certificate & diploma & certificate/diploma \\
interest & high & middle & middle & high \\
flexibility & high & low & low & high \\
\hline
\end{tabular}


The results are based on the opinions of experts who have had an extensive experience in the sphere of international higher education (over 15 years). In total, 5 experts took part in the study. Data obtained from the experts' analysis are averaged and presented in Table 4.

Table 4

Pros and Cons Analysis of Educational Models

\begin{tabular}{|c|c|}
\hline Pros & Cons \\
\hline \multicolumn{2}{|c|}{ Cross-border online courses for international students } \\
\hline using the latest digital and communications technology & long preparatory work \\
\hline there are no problems of life and leisure of students & costs of the latest hardware and software \\
\hline no need to change place of residence & additional costs for promoting online courses abroad \\
\hline distance learning & lack of immersion in the linguistic and cultural environment \\
\hline \multicolumn{2}{|c|}{ Double diploma programs } \\
\hline two higher education diplomas at the time of receiving one & students are not ready for double study load \\
\hline world level education & students need to leave home for $1-2$ years \\
\hline individual learning path & $\begin{array}{l}\text { long preparatory work (conclusion of contracts, paperwork, } \\
\text { etc.) }\end{array}$ \\
\hline professional knowledge in different languages & the need to solve domestic problems \\
\hline \multicolumn{2}{|c|}{ Visiting professor invitation } \\
\hline $\begin{array}{l}\text { teacher is a native speaker of a foreign language } \\
\text { possibility of informal communication with a foreign teacher } \\
\text { the opportunity to establish international relations with foreign } \\
\text { universities }\end{array}$ & $\begin{array}{l}\text { embedding a course in a traditional learning system is needed } \\
\text { foreign teachers need high salaries } \\
\text { additional costs for adaptation, life and leisure of a foreign } \\
\text { teacher }\end{array}$ \\
\hline \multicolumn{2}{|c|}{ Summer courses } \\
\hline flexible program & short term \\
\hline high interest of students & difficult to find teachers for the summer \\
\hline high intensity & additional costs for providing life and leisure for students \\
\hline immersion in the linguistic and cultural environment & \\
\hline
\end{tabular}

For comparison of international education different models' advantages and disadvantages different methods of analysis were applied in our study. The first one is called The Pros and Cons Analysis. It is a qualitative method of analysis comparing positive with negative aspects). Experts in correspondent field compile lists of pros and cons on strengths and weaknesses basis for each alternative.

The second method used to evaluate different models of international education was the KepnerTregoe Method used in decision-making activity. It provides assessment criteria for information collection, systematization and evaluation before making a decision. "The Kepner-Tregoe decision-making method based on the ultimate goal of any decision becomes the best choice of possible options, it must be noted that it is the "best", but not ideal in this situation. Despite the comparative analysis of solution options, the risk remains. Using the Kepner-Tregoe matrix reduces the risks associated with making a wrong decision" (Kepner-Tregoe Portal ).

By using Pros and Cons Analysis we show that each international educational model has advantages and disadvantages in its activities. For comparative analysis, it is necessary to identify priority assessment of less important criteria. This can be done with Kepner-Tregoe method (Table 5). 
Makarova et al. (2021). International student exchange management as factor of educational services development, International Journal of Cognitive Research in Science, Engineering and Education (IJCRSEE), 9(1), 75-90.

Table 5

Kepner-Tregoe matrix of Cross-border online courses for international students. Description of factors and their significance

\begin{tabular}{ccccc}
\hline Criterion & Importance & Description & Score & Total \\
\hline competences & 9 & middle & 7 & 63 \\
revenue per 1 student & 8 & $1000-5000$ rub & 8 & 64 \\
time & 7 & $72-600$ h/ 1-6 month & 5 & 35 \\
flexibility & 6 & high & 9 & 54 \\
diploma/ certificate & 6 & diploma/ certificate & 5 & 30 \\
students' number & 6 & 50 & 10 & 60 \\
interest & 5 & high & 9 & 45 \\
cost per 1 student & 5 & 1000 rub & & 50 \\
\end{tabular}

All the criteria were analysed and evaluated by experts according to their significance. The totals were calculated by multiplying the rank of each criterion by the score of each criterion alternative, as a result total estimates were obtained. The analysis of cross-border online courses programmes results and evaluation are presented in Table 5.

Table 6

Kepner-Tregoe matrix of Summer courses for international students. Description of factors and their significance

\begin{tabular}{|c|c|c|c|c|}
\hline Criterion & Importance & Description & Score & Total \\
\hline competences & 9 & middle & 7 & 63 \\
\hline revenue per 1 student & 8 & 2000 rub & 8 & 64 \\
\hline time & 7 & $40 \mathrm{~h} / 2$ weeks & 8 & 56 \\
\hline flexibility & 6 & high & 10 & 60 \\
\hline diploma/ certificate & 6 & certificate & 2 & 12 \\
\hline students' number & 6 & 15 & 7 & 42 \\
\hline interest & 5 & high & 9 & 45 \\
\hline \multirow[t]{2}{*}{ cost per 1 student } & 5 & 1600 rub & 8 & 40 \\
\hline & & & & 382 \\
\hline
\end{tabular}

"To fill in the matrix for each alternative, various digital indicators are determined and the value for each factor is calculated, followed by the weight of each solution. In Kepner-Tregoe analysis each evaluation criterion is first scored based on its relative importance to the other criteria ( 1 = least; 10 = most)" (Egorova and Makarova, 2020). According to expert evaluation and after different methods application, for foreign students' benefit summer courses (382 points) and cross-border online courses (401 points) were considered the most relevant way of educational services export.

\section{Discussions}

When actual numerical data are unavailable, subjective reasoning, opinions, and/or consensus scoring can be substituted and documented in the final report instead. Research has demonstrated that simplified decision analysis methods (SMART) are robust and replicate decisions made from more complex analysis with a high degree of confidence.

The experts involved in the study were specialists in the field of higher education with extensive experience in higher education institutions (over 15 years). In total, 5 experts took part in the study. All data obtained from experts were averaged and presented in tabular form.

The Simple Multi Attribute Rating Technique (SMART) (Baker et al., 2002) utilizes simple utility relationships and simple scale. Five, seven, and ten point scales are the most commonly used. The 
SMART methodology allows using less of the scale range with data not discriminated adequately.

For the basis of the analysis we take the criteria of cost, students' number, competences, training time, diploma/ certificate, students' interest, flexibility. Weighted criteria estimates are summarized in the totals shown in Table 7.

Table 7

Rank factor estimates of the Simple Multi Attribute Rating Technique (SMART) factors

\begin{tabular}{ccccc}
\hline Criteria & Summer courses & Visit-professor & Double diploma & Online courses \\
\hline cost & 4 & 3 & 1 & 5 \\
students' number & 4 & 1 & 1 & 5 \\
competences & 3 & 2 & 5 & 4 \\
time & 5 & 4 & 1 & 2 \\
diploma/ certificate & 2 & 1 & 5 & 3 \\
interest & 4 & 3 & 2 & 4 \\
flexibility & 4 & 2 & 2 & 4 \\
\hline
\end{tabular}

A performance rating scale of $1-5$ is used when a rating of "1" always means worse performance $(0)$, and a rating of " 5 " always means better performance (1). The normalized values in Table 3 are converted to usable values from 0 to $1(1=0,2=.25,3=.5,4=.75,5=1.0)$. Weighted criteria estimates are summarized in the totals shown in Table 8.

Table 8

Utility values of the Simple Multi Attribute Rating Technique (SMART) factors

\begin{tabular}{ccccc}
\hline Criteria & Summer courses & Visit-professor & Double diploma & Online courses \\
\hline cost & 0.75 & 0.5 & 0 & 1 \\
students' number & 0.75 & 0 & 0 & 1 \\
competences & 0.5 & 0.25 & 1 & 0.75 \\
time & 1 & 0.75 & 0 & 0.25 \\
diploma/ certificate & 0.25 & 0 & 1 & 0.5 \\
interest & 0.75 & 0.5 & 0.25 & 0.75 \\
flexibility & 0.75 & 0.25 & 0.25 & 0.75 \\
& 4,75 & 2,25 & 2,5 & 5 \\
& 0,68 & 0,32 & 0,36 & 0,71 \\
& $67,9 \%$ & $32,1 \%$ & $35,7 \%$ & $71,4 \%$ \\
\hline
\end{tabular}

The results of calculations are presented in Table 8 and show the highest utility ratings received by two of the alternatives we proposed - summer courses (67.9\% utility) and online courses $(71.4 \%$ utility). Thus, it is necessary to choose summer and online courses as the best alternatives.

After comparative analysis of international educational activities in higher education has been accomplished, summer courses and cross-border online courses have proved to be the most effective and efficient way of getting higher education abroad. To improve the management of international activities, new forms of international student exchange and other options for exporting educational services have been proposed. Pros and Cons Analysis revealed the advantages and disadvantages of the proposed areas of development. Kepner-Tregoe Analysis and Simple Multiple Attribute Evaluation Method allowed evaluating these alternatives by the criteria cost, students 'number, competences, training time, education document, interest for students, program flexibility. The most effective ones are summer courses and e-learning programs. Using these forms of international student exchange will attract new foreign students and increase the level of TMEl income from the export of educational services. 
Makarova et al. (2021). International student exchange management as factor of educational services development, International Journal of Cognitive Research in Science, Engineering and Education (IJCRSEE), 9(1), 75-90.

\section{Conclusions}

A theoretical analysis of key concepts in the field of international education management has shown that the most significant factor in international education management is the stimulation of all forms of academic mobility. International student exchanges contribute to advancement of educational goods and services in the world market and ultimately lead to the development of the export potential of the RF higher education. Modern programs and models for exporting educational services on the international education market are very diverse, but in modern conditions, universities tend to use most of them, which makes it possible to diversify the educational services market.

In TMEl, international educational activities have been carried out since 1996 according to existing educational programs, students' cultural and educational exchanges, visiting professors, and participation in international scientific and educational events. For the regional private educational organization TMEI, several alternatives were proposed to improve the management of international student exchanges in the export of higher educational goods and services. The organization of short-term summer courses for foreign citizens, the development of programs for cross-border online training, invitation of more foreign visiting professors, and the development of double degree programs were proposed.

\section{Acknowledgements}

The authors express their gratitude to Southern Federal University, Taganrog Institute of Management and Economics and Don State Technical University for their assistance that made the following Project possible.

\section{Conflict of interests}

The authors declare no conflict of interest.

\section{References}

Amirov, R.A. (2018). Eksport obrazovatel'nykh uslug kak vazhneyshiy faktor povysheniya konkurentosposobnosti i ekonomicheskogo razvitiya strany [Export of educational services as the most important factor of Competitiveness and Economic Development of the Country]. Upravlencheskoye konsul'tirovaniye [Administrative Consulting], 8(116), 71-81. https://doi.org/10.22394/1726-1139-2018-8-71-81

Bailey, L., \& Cooker, L. (2018). Who Cares? Pro-social education within the programmes of the International Baccalaureate. Journal of Research in International Education, 17(3), 228-239. https://doi.org/10.1177/1475240918816405

Baker, D., Bridges, D., Hunter, R., Johnson, G., Krupa, J., Murphy, J., \& Sorenson, K. (2002). Guide to decisionmaking methods. developed for the department of energy, WSRC-IM-2002-00002, 2. Retrieved from https://www.researchgate.net/ publication/255621095_Guidebook_to_Decision-Making_Methods

Barabanova, S.V., Kaybiyaynen, A.A., Kraysman, N.V. (2019). Digitalization of Engineering Education in a Global Context (Review of International Conferences). M.: Higher education in Russia. 1. 94-103.

Bedenlier, S., Kondakci, Y., \& Zawacki-Richter, O. (2018). Two Decades of Research Into the Internationalization of Higher Education: Major Themes in the Journal of Studies in International Education (1997-2016). Journal of Studies in International Education, 22(2), 108-135. https://doi.org/10.1177/1028315317710093

Bischof, L. (2014). Franchising, Validation, and Branch Campuses in the European Union. International Higher Education, (74), 16-17. https://doi.org/10.6017/ihe.2014.74.5468

Bondarenko, V.V., Zaugarov, V.V., Seleznev, P.S.,\& Yudina, V.A. (2018). Kontseptsiya sovershenstvovaniya universitetskogo obucheniya inostrannykh studentov v Rossiyskoy Federatsii v ramkakh politiki "myagkoy sily" [The concept of improving university education of foreign students in the Russian Federation in the framework of the policy of "soft power"]. Gumanitarnyye nauki. Vestnik Finansovogo universiteta [Humanities. Bulletin of the University of Finance]. 5(35). 6-18. https://doi.org/10.26794/2226-7867-2018-8-5-6-18

Bridges, W. \& Bridges, S. (2017). Managing Transitions, 25th anniversary edition: Making the Most of Change. Hachette Books. 208.

Buckner, E. (2017). The Worldwide Growth of Private Higher Education: Cross-national Patterns of Higher Education Institution Foundings by Sector. Sociology of Education, 90(4), 296-314. https://doi.org/10.1177/0038040717739613

Cai, Y., \& Etzkowitz, H. (2020). Theorizing the Triple Helix model: Past, present, and future. Triple Helix, 1(aop), 1-38. https:// doi.org/10.1163/21971927-bja10003

Dakowska, D. (2017). Competitive universities? The impact of international and European trends on academic institutions in the 'New Europe.' European Educational Research Journal, 16(5), 588-604. https://doi.org/10.1177/1474904116688024

EAIE, European Association for International Education: official website. Retrieved from https://www.eaie.org/

Egorova I. A. \& Makarova, E.L. (2020). Managerial decision-making analysis for various forms of interna-tional educational activities organization in higher education. Modern Science. 2-2. 17-23. Retrieved from https://www.elibrary.ru/item. asp?id $=42515313$

Etzkowitz, H. (2016). The Entrepreneurial University: Vision and Metrics. Industry and Higher Education, 30(2), 83-97. https://

www.ijcrsee.com 
Makarova et al. (2021). International student exchange management as factor of educational services development, International Journal of Cognitive Research in Science, Engineering and Education (IJCRSEE), 9(1), 75-90.

doi.org/10.5367/ihe.2016.0303

Federal State Statistic Service: official website. Retrieved from https://rosstat.gov.ru/

Gaebel, M., Kupriyanova, V., Morais, R., \& Colucci, E. (2014). E-Learning in European Higher Education Institutions, European University Association.

Gaus, O., \& Raith, M. G. (2016). Commercial transfer - A business model innovation for the entrepreneurial university. Industry and Higher Education, 30(3), 183-201. https://doi.org/10.1177/0950422216653197

Hawawini, G. (2016). The internationalization of higher education and business schools: A critical review. Springer, 85. https:// doi.org/10.1007/978-981-10-1757-5

Internet World Stats. Retrieved from https://www.internetworldstats.com/

Ismailova, G., Alma, M., Gulbarshyn, A., Nurgul, B., Sarash, K., \& Malik, S. (2020). Determining professional mobility levels of secondary school teachers. International Journal of Cognitive Research in Science, Engineering and Education, 8(3). 39-45. https://doi.org/10.23947/2334-8496-2020-8-3-39-45

Kepner-Tregoe Portal Retrieved from https://www.kepner-tregoe.com

Knight, J. (2016). Transnational Education Remodeled: Toward a Common TNE Framework and Definitions. Journal of Studies in International Education, 20(1), 34-47. https://doi.org/10.1177/1028315315602927

Knight, J. (2018). International Education Hubs. In: Meusburger P., Heffernan M., Suarsana L. (eds) Geographies of the University. Knowledge and Space, vol 12. Springer, Cham. 637-655. https://doi.org/10.1007/978-3-319-75593-9_21

Makarova, E. A., \& Makarova, E. L. (2018). Blending pedagogy and digital technology to transform educational environment. International Journal of cognitive research in science, engineering and education, 6(2), 57-66. https://doi.org/10.5937/ ijcrsee1802057M

Makarova, E. A., Makarova, E. L., \& Hjaltadottir, R. E. (2019). Analysis of the satisfaction degree of students participating in international educational projects. In SHS Web of Conferences (Vol. 70, p. 02014). EDP Sciences. https://doi. org/10.1051/shsconf/20197002014

Makarova, E. A., Makarova, E. L., \& Korsakova, T. V. (2019). The role of globalization and integration in interdisciplinary research, culture and education development. Journal of History Culture and Art Research, 8(1), 111-127. http://dx.doi. org/10.7596/taksad.v8i1.1957

Mawer, M. (2017). Approaches to analyzing the outcomes of international scholarship programs for higher education. Journal of Studies in International Education, 21(3), 230-245. https://doi.org/10.1177/1028315316687009

Mcvicar, M. (2015). The internationalization of higher education: an emerging political agenda. Sravnitel'naya politika [Comparative politics], 1(18). 82-89.

Menzies, J. L., \& Baron, R. (2014). International postgraduate student transition experiences: The importance of student societies and friends. Innovations in Education and Teaching International, 51(1), 84-94. https://doi.org/10.1080/1470 3297.2013 .771972

NAFSA, Association of International Educators: official website. Retrieved from https://www.nafsa.org

OECD/UIS/Eurostat (2019) Retrieved from https://stats.oecd.org/

Pashakhina, E.A. (2020). Rynok obrazovatel'nykh uslug Rossii v usloviyakh reformirovaniya sistemy vysshego obrazovaniya [The market of educational services in Russia in the context of reforming the higher education system]. Vestnik Tomskogo gosudarstvennogo universiteta. Ekonomika [Bulletin of Tomsk State University. Economy]. 49, 110-121. https://doi.org/10.17223/19988648/49/8

QS world university rankings (2020). Retrieved from https://www.topuniversities.com/university-rankings/world-universityrankings $/ 2020$

Silakova L.V. (2017). Upravleniye transformatsiyey biznes-protsessov sovremennogo universiteta v Rossii. [Transformation management of business processes of a modern university in Russia]. Voprosy innovatsionnoy ekonomiki [Issues of innovative economy]. 4. 361-372.

UNESCO official website. Retrieved from https://en.unesco.org/

Ussenova, A., Malakhova, I., Shmidt, M., Tuliepova, S. ., \& Tynyskhanova, A. (2020). Conceptual framework of the model of forming interethnic tolerance in the multicultural environment of the university. International Journal of Cognitive Research in Science, Engineering and Education, 8(2), 15-26 https://doi.org/10.5937//JCRSEE2002015U 